\title{
PERBEDAAN PEMBERIAN JAMBU BIJI MERAH (PSIDIUM GUAJAVA) DAN BIT (BETA VULGARIS) TERHADAP KADAR HEMOGLOBIN IBU HAMIL
}

\author{
Bunga Tiara Carolin ${ }^{1}$, Siti Syamsiah ${ }^{2}$, Deresiyana $^{3}$ \\ ${ }^{1,2,3}$ Program Studi Kebidanan Program Sarjana Terapan, Fakultas Ilmu Kesehatan, Universitas Nasional \\ Email Korespondensi: bunga.tiara@civitas.unas.ac.id
}

Kata kunci: Jus jambu biji merah; jus bit; kadar hemoglobin
Keywords: Red guava juice; beet juice: hemoglobin level

\section{Info Artikel}

Tanggal dikirim: 01-11-2020

Tanggal direvisi: $04-03-2021$

Tanggal diterima: $13-07-2021$

DOI Artikel:

10.36341/jomis.v5i2.1517

Creative Commons Attribution-

NonCommercial-ShareAlike 4.0 International License.

\begin{abstract}
ABSTRAK
Salah satu masalah penyebab AKI di Indonesia adalah anemia. Berdasarkan The Global Prevelence Of Anemia, prevelensi anemia ibu hamil sebesar 28,3\%. Angka Kejadian Anemia di Puskesmas Rangkapan Jaya peroleh 64,3\%. Anemia terjadi karena perubahan fisiologis dan diperberat dengan kekurangan gizi. Upaya yang dapat dilakukan agar ibu hamil tidak megalami anemia adalah konsumsi tablet Fe, memperbaiki menu makanan dan menambahkan substansi makanan kaya vitamin $\mathrm{C}$ seperti yang terdapat pada buah jambu biji merah dan buah bit. Tujuan dalam penelitian ini adalah untuk mengetahui perbedaan pemberian antara jambu biji merah dan bit terhadap kadar hemoglobin pada ibu hamil. Metodologi yang digunakan yaitu Quasy Eksperimen dengan rancangan Two Group Pretest Posttest Design. Populasi dalam penelitian ini seluruh ibu hamil trimester III. Sampelnya sebanyak 30 orang dengan intervensi jus jambu biji merah dan jus bit. Diberikan selama 14 hari sebanyak $250 \mathrm{cc}$. Hasil Penelitian terdapat perbedaan pemberian jus jambu biji merah dan jus bit terhadap kadar hemoglobin pada ibu hamil. Dengan nilai rata sebelum dan sesudah pemberian jus buah jambu biji merah $8,4 \mathrm{~g} / \mathrm{dl}$ menjadi $11,5 \mathrm{~g} / \mathrm{dl}$ dan nilai rata sebelum dan sesudah jus bit 8,5 g/dl menjadi 10,2 g/dl. p-value sebesar 0,001.Simpulannya, Jus jambu biji merah lebih efektif terhadap perubahan kadar hemoglobin.
\end{abstract}

\section{ABSTRACT}

One of the problems causing MMR in Indonesia is anemia. Based on the global prevention of Anemia, the prevalence of anemia in pregnant women is $28.3 \%$. The anemia rate in Rangkap Jaya Health Center is 64.3\%. Anemia occurs due to physiological changes and is aggravated by malnutrition. Efforts that can be done so that pregnant women do not experience anemia are consumption of Fe tablets, improve diet and add vitamin $C$-rich food substances such as those found in red guava fruit and beets. The purpose of this study was to determine the difference between giving red guava juice and beet juice on hemoglobin levels in pregnant women. Methodology this study uses a Quasy Experiment with a Two Group Pretest Posttest Design. The population in this study are all trimester III pregnant women. The samples of this study arev30 people with the intervention of red guava juice and beet juice. Given for 14 days which are $250 \mathrm{cc}$. Results: That there are differences in the provision of red guava juice and beet juice on hemoglobin levels in pregnant women. With the average value before and after administration of red guava fruit juice is $8.4 \mathrm{~g} / \mathrm{dl}$ to $11.5 \mathrm{~g} / \mathrm{dl}$ and the average value before and after beet juice is $8.5 \mathrm{~g} / \mathrm{dl}$ to $10.2 \mathrm{~g} / \mathrm{dl}$. p-value of 0.001. The conclusions is Red guava juice is more effective against changes in hemoglobin levels. 


\section{PENDAHULUAN}

Salah satu masalah dan penyebab tidak langsung meningkatnya AKI di Indonesia masih tinggi adalah anemia pada ibu hamil. Di negara berkembang sekitar 40\% kematian ibu hamil berkaitan dengan anemia dalam kehamilan. Anemia kehamilan yang sering terjadi disebabkan karena kekurangan zat besi dan perdarahan akut bahkan keduanya sering menjadi penyebab yang saling berhubungan[1]. Menurut WHO (2015) yang berdasarkan The Global Prevelence Of Anemia, prevelensi anemia pada ibu hamil sebesar $28,3 \%$ [2].

Anemia ibu hamil memberikan pengaruh di setiap negara maju, ataupun negara berkembang. 32,4 juta ibu yang hamil di dunia menderita anemia, dengan jumlah yang berbeda-beda antara wilayah, tertinggi di wilayah Asia Tenggara 48,7\%, Afrika 46,3\%, Timur Tengah 38,9\%, Eropa 25,6\%, dan terendah wilayah Pasifik Barat 24,3\%. Sedangkan berdasarkan negara tertinggi di Senegal (63\%), dan terendah di Amerika Serikat (17\%)[2].

Berdasarkan Kemenkes RI (2018) prevelensi kejadian anemia ibu hamil di Indonesia mencapai 48,9\% dengan Prevelensi anemia ibu hamil tertinggi pada umur 15 - 24 tahun $(84,6 \%)$, dan terendah usia 45 - 54 tahun (24\%)[3]. Sedangkan prevelensi anemia di Provinsi Jawa Barat pada tahun 2017 sebanyak 51,7\% dan anemia di di wilayah kerja puskesmas Rangkapan Jaya tahun 2019 selama 3 bulan terakhir sebanyak $64,3 \%$.

Anemia merupakan penyakit kekurangan eritrosit yang mana jika jumlah eritrosit berkurang, asupan oksigen dan aliran darah menuju otak juga semakin berkurang[4] Hemoglobin adalah protein berpigmen merah yang terdapat dalam sel darah merah. Hemoglobin mengandung kira-kira 95 persen besi dan berfungsi membawa oksigen dengan cara mengikat oksigen (oksihemoglobin) dan diedarkan ke seluruh tubuh untuk kebutuhan metabolisme[5].
Umumnya anemia terjadi karena perubahan fisiologis saat hamil dan diperberat dengan kekurangan gizi (pola makan tidak seimbang). Anemia yang terjadi selama masa kehamilan berdampak besar, baik pada ibu maupun janin, diantaranya terjadinya abortus, persalinan prematur (kurang bulan), tumbuh kembang janin dalam rahim terhambat, kehamilan anggur (mola hidatidosa), bayi baru lahir rendah (BBLR), rentan terkena infeksi, perdarahan antepartum, ketuban pecah dini, gangguan his saat proses persalinan, kala 1 memanjang, subinvolusi uteri, serta infeksi puerperium [4].

Petugas kesehatan sebagai pengayom masyarakat merupakan faktor utama yang bisa memberikan asuhan kebidanan Ante Natal Care (ANC) pada ibu hamil secara maksimal. Petugas kesehatan diharapkan mampu memberikan pengaruh dan memberikan perubahan perilaku pada masayarakat khusunya ibu hamil dalam mengatasi anemia. Seperti pemberian tablet Fe selama kehamilan sebanyak 90 tablet, konseling pemenuhan nutrisi bumil dengan pemberian makanan tambahan bumil selama hamil (PMT), dan menganjurkan konsumsi jenis buah dan sayur yang mampu memberiakan pengaruh pada kadar hemoglobin ibu selama kehamilan. [4].

Salah satu langkah yang dapat ditempuh untuk mencegah terjadinya anemia yaitu dengan memberikan tablet Fe, memperbaiki menu makanan yang akan di konsumsi. Seperti meningkatkan konsumsi makanan yang banyak mengandung zat besi seperti telur, susu, hati, ikan, daging, kacang kacangan, sayuran berwarna hijau tua, dan buahbuahan. Bisa pula menambahkan substansi yang memudahkan penyerapan zat besiseperti vitamin $\mathrm{C}$, air jeruk dan jenis buah-buahan seperti jambu biji merah dan buah bit. Sebaliknya, substansi penghambat penyerapan zat besi seperti teh dan kopi patut dihindari [4].

Cara non-farmakologis mengatasi anemia pada ibu hamil seperti pemberian 
telur ayam ras rebus[6] maupun yang berasal dari tumbuhan seperti pemberian jus daun kelor dan kacang hijau yang mampu meningkatkan kadar hemoglobin ibu hamil[7]. Ada juga yang menggunakan ekstrak jeruk, dimana mengkonsumsi ekstrak jeruk bersamaan denga tablet zat besi dapat menambah kadar hemoglobin pada ibu hamil yang menderita anemia[8]. Serta mengkonsumsi jus tomat dan jus bayam juga dapat mempengaruhi kadar hemoglobin pada ibu hamil trimester 3 [9].

Selain itu ada juga buah jambu biji merah (Psidium Guajava Linn) merupakan jenis buah yang kaya dengan vitamin $C$ dan bagus untuk membantu penyerapan zat besi dalam tubuh selain itu buah jambu biji merah memeliki kandungan vitamin $\mathrm{A}, \mathrm{E}$, $\mathrm{K}$, serta mengandung fosfor, kalsium, kalium, protein dan besi yang bermanfaat untuk menjaga imunitas, mencegah infeksi, membantu elaksasi dan mencegah terjadinya anemia sedangkan buah bit (Beta Vulgaris) memiliki kandung vitamin A, B, C, karbohidrat, protein, lemak dan mineral seperti zat besi, kalsium serta fosfor[10]. Bit memiliki kadar asam folat yang tinggi dibandingkan dengan buah lainnya[11]. Dimana buah ini bisa membantu proses penyerapan zat besi dan membantu mengurangi masalah anemia [12]. Beta Vulgaris merupakan alternative pengobatan yang terdapat zat besi sehingga dapat menaikkan kadar hb dalam darah[13].

Melihat penelitian yang sudah dilakukan sebelumnya terkait jus bit dan jus jambu biji merah yang efektif untuk memberikan perubahan pada kadar hemoglobin ibu hamil, maka peneliti bermaksud untuk melakukan penelitian tentang Perbedaan Pemberian Psidium Guajava dan Beta Vulgaris Terhadap Kadar Hb Ibu Hamil Anemia Di Puskesmas Rangkapan Jaya Depok 2019.

\section{TINJAUAN PUSTAKA}

Anemia yang dialami selama hamil merupakan masalah kesehatan di masyarakat terutama di berbagai Negara yang sedang berkembang[14]. Anemia merupakan penyakit kekurangan eritrosit yang mana jika jumlah eritrosit berkurang, asupan oksigen dan aliran darah menuju otak juga semakin berkurang[15].

Eritrosit hidup dan beredar dalam darah tepi rata-rata 120 hari. Molekul hemoglobin adalah unit fungsional dari sel-sel darah merupakanstruktur protein komplek yang berada didalam sel darah merah. Sel darahmerah (eritrosit) dibuat dalam sumsum tulang. Banyak faktor lain yang terlibat dalam produksinya, misalnya besi merupakan komponen yang sangat penting dari molekul hemoglobin dan hormone eritropetin, hormone yang dikeluarkan oleh ginjal, merangsang pembentukan sel darahmerah disumsum tulang. Setelah 120 hari eritrosit terjadi sebelumwaktunya $(<120$ hari $)$, maka proses ini disebut sebagai hemolisis. Hemolisis yang terjadi pada eritrosit akan mengakibatkan terurainya komponenkomponen hemoglobin [16].

Hemoglobin adalah protein berpigmen merah yang terdapat dalam sel darah merah. Hemoglobin mengandung kira-kira 95 persen besi dan berfungsi membawa oksigen dengan cara mengikat oksigen (oksihemoglobin) dan diedarkan ke seluruh tubuh untuk kebutuhan metabolisme[5].

Fungsi fisiologi utama hemoglobin adalah mengatur pertukaran oksigen dengan karbondioksida didalam jaringan tubuh. Mengambil oksigen dari paru-paru kemudian dibawah keseluruh tubuh untuk dipakai sebagai bahan bakar. Membawa karbindioksida dari jaringan-jaringan tubuh sebagai hasil metabolisme ke paru paru untuk dibuang[17].

Penyebab anemia pada kehamilan ada 2 faktor. Faktor pertama status anemia pada kehamilan terjadi secara langsung disebabkan oleh malnutrisi, kurang zat besi, malabsorpsi, dan penyakit kronis (Tubercolosis (TBC), malaria, cacingan, dan lain-lain. Sedangkan faktor kedua tidak langsung antara lain dapat disebabkan oleh umur ibu waktu hamil, pengetahuan tentang anemia pada kehamilan, paritas, kepatuhan konsumsi 
Fe, pemenuhan subtansi tambahan dan kualitas pelayanan kesehatan yang diberikan oleh bidan[15].

Anemia difisiensi besi disebabkan oleh kekurangan zat besi yang mana berperan dalam pembentukan hemoglobin. Beberapa faktor lain yang dapat menyebabkan anemia defisiensi besi adalah faktor nutrisi atau kurang gizi, kehilangan zat besi sebagai akibat perdarahan menahun, kebutuhan zat besi meningkat seperti dalam kehamila serta gangguan absorbsi besi dan penyakit kronik[18].

Gejala fisik umum dari anemia adalah lesu, lemah, letih, lelah, mudah lupa, sering mengaluh pusing dan mata berkunang-kunang serta gejala lebih lanjut adalah kelopak mata, bibir, lidah, kulit dantelapak tangan menjadi pucat. Gejala lainnya adalah kehilangan nafsu makan, sulit berkonsentrasi, sensitive terhadap dingin, bernapas cepat saat berolahraga, kulit kering dan pucat, rambut rontok, serta kuku rapuh dan berbentuk sendok[16].

Bahaya anemia pada ibu hamil saat persalinan: gangguan his-kekuatan mengejan, kala I dapat berlangsung lama dan terjadi partus terlantar, kala II berlangsung lama sehingga dapat melelahkan dan sering memerlukan tindakan operasi kebidanan, kala III dapat diikuti retensio plasenta dan perdarahan postpartum akibat atonia uteri, kala IV dapat terjadi perdarahan post partum sekunder dan atonia uteri. Pada kala nifas: terjadi subinvolusi uteri yang menimbulkan perdarahan post partum, memudahkan infeksi puerperium, pengeluaran ASI berkurang, dekompensasi kordis mendadak setelah persalinan, anemia kala nifas, mudah terjadi infeksi mammae[1].

Jambu biji memiliki kandungan vitamin $\mathrm{C}$ yang tinggi dimana dua kali lebih banyak dari jeruk manis hanya $49 \mathrm{mg}$ per 100 g. [19].

Adapun bit dengan kadar air yang cukup tinggi dan memiliki kandungan vitamin A, B, dan C. Selain itu, bit juga mengandung karbohidrat, protein, dan lemak yang berguna untuk kesehatan tubuh. Mineral lainnya juga terkandung dalam bit seperti zat besi, kalsium dan fosfor[20].

Beberapa penelitian yang sudah di lakukan terdahulu seperti penelitian oleh Utaminingtyas (2017) yang berjudul manfaat umbi bit (Betav Vulgaris) terhadap peningkatan kadar hemoglobin ibu hamil di dapatkan hasil bahwa umbi bit merupakan alternatif pengobatan non farmokologi mengandung zat besi yang dapat meningkatkan kadar hemoglobin [13].

Suryandari \& Happinasari, (2015) mengatakan ada perbedaan peningkatan kadar Hemoglobin ibu hamil yang dilakukan dengan diberikan $\mathrm{Fe}$ dan $\mathrm{Fe}+$ bit setelah mengkonsumsi $500 \mathrm{ml}$ juice buah bit selama 7 hari, dengan rata-rata tingkat $\mathrm{Hb}$ ibu hamil sebelum dan sesudah mengonsumsi $\mathrm{Fe}$ adalah $8,40 \mathrm{~g} \%$ menjadi $9,70 \mathrm{~g} \%$, sedangkan rata-rata tingkat $\mathrm{Hb}$ pada ibu hamil sebelum dan sesudah diberi $\mathrm{Fe}+$ bit adalah 9,70 g\% menjadi 10,30 $\mathrm{g} \%$ [12].

Selanjutnya penelitian yang dilakukan Stephana, et al., (2017) dengan pemberian jus bit sebanyak $250 \mathrm{cc}$ selama 7 hari bahwa ada perubahan kadar $\mathrm{Hb}$ ibu hamil antar kelompok control dan intervensi. Ini menunjukkan pemberian bit efektif terhadap perubahan kadar hemoglobin ibu hamil[11]. Hasil penelitian Liananiar, et al (2020) berdasarkan analisis uji t-test berpasangan pada kelompok eksperimen menunjukkan bahwa nilai $p$ value adalah 0,002 hal ini berarti $p<0,05$, maka terdapat perbedaan kadar hemoglobin yang signifikan antara kadar hemoglobin pre-test dan kadar hemoglobin post-test dengan mengkonsumsi buah bit[21].

Hasil Penelitian Yanuaringsih (2018) bahwa ada perbedaan efektifitas pemberian jus jambu biji merah dan konsumsi sereal terhadap kadar $\mathrm{Hb}$ pada ibu hamil. Dengan rata kadar Hb sesudah diberikan jus jambu biji merah 12,5 dan konsumsi Seral 11,8 selama 14 hari sehingga dapat disimpulkan bahwa 
jusjambu biji merah lebih efektif terhadap perubahan kadar $\mathrm{Hb}$ pada ibu hamil[22].

Winarni, et al (2020) dalam penelitiannya mengatakan pemberian jus jambu biji merah dapat menjadi alternative dalam meningkatkan kadar hemoglobin pada ibu hamil anemia[23]. Yantina (2018) dalam penelitiannya juga menyimpulkan ada pengaruh konsumsi jambu biji merah terhadap kadar hemoglobin pada ibu hamil trimester I[24].

\section{METODE}

Penelitian ini bersifat kuantitatif menggunakan Quasi eksperimental dengan pendekatan Two Group Pretest Posttest Design. Lokasi penelitian berada di Puskesmas Rangkapan Jaya Depok Bulan Desember 2019 - Januari 2020. Populasinya yaitu ibu hamil Trimester III dengan kategori anemia sedang. Sampel dalam penelitian ini sebanyak 30 responden dimana 15 responden diberikan jus bit dan 15 orang lainnya diberikan jus jambu biji merah masing-masing selama 14 hari yang mana teknik pengambilan sampel menggunakan purposive sampling. Pada hasil homogenitas didapatkan data homogen dan uji normalitas menggunakan Shapiro Wilk didapatkan data berdistribusi normal sehingga analisis data yang dilakukan dalam penelitian menggunakan Dependent $t$ test dan Independen $t$ test. Instrumen Penelitian menggunakan lembar observasi. Alat pemeriksaan menggunakan Easy Touch, Kapas alkohol, dan Blood Lancetf.

Intervensi pada kelompok jus jambu biji merah dengan memberikan buah jambu biji merah sebanyak $150 \mathrm{mg}$ yang di olah dalam bentuk juice dengan tambahan air matang dingin $100 \mathrm{ml}$ dan 1 sendok gula pasir dan dikemas dalam wadah gelas plastik sebanyak $250 \mathrm{cc}$ dan di distribusikan kepada kelompok perlakuan untuk di konsumsi rutin selama 14 hari. Sedangkan pada intervensi kelompok jus bit dengan memberikan bit sebanyak 150 mg yang di olah dalam bentuk juice dengan tambahan air matang dingin $250 \mathrm{ml}$ dan 1 sendok gula. sebanyak $250 \mathrm{cc}$ dan didistribusikan kepada kelompok perlakuan untuk di konsumsi rutin selama 14 hari.

\section{HASIL DAN PEMBAHASAN Analisis Univariat}

Tabel 1.

Distribusi frekuensi hemoglobin sebelum dan sesudah diberikan jus jambu biji merah dan jus bit

\begin{tabular}{lccccc}
\hline \multicolumn{1}{c}{ Variabel } & N & Minimum & Maximum & Mean & SD \\
\hline Jus Jambu Biji Merah & & & & & \\
Sebelum & 15 & 7,8 & 8,9 & 8,420 & 0,3688 \\
Sesudah & 15 & 9,7 & 12,9 & 11,513 & 1,0267 \\
\hline Jus Bit & 15 & 7,8 & 8,9 & 8,560 & 0,3481 \\
Sebelum & 15 & 8,4 & 11,8 & 10,153 & 0,9606 \\
Sesudah & & & &
\end{tabular}

Pada Tabel 1. diketahui rata-rata kadar $\mathrm{Hb}$ sebelum diberikan intervensi jus jambu biji merah adalah 8,4 g/dl dan sesudah diberikan intervensi adalah 11,5 g/dl. Sedangkan rata-rata kadar hemoglobin pada Ibu hamil sebelum diberikan intervensi jus bit adalah $8,5 \mathrm{~g} / \mathrm{dl}$ dan sesudah diberikan intervensi jus bit adalah $10,1 \mathrm{~g} / \mathrm{dl}$.

Anemia adalah suatu keadaan dimana jumlah sel darah merah atau jumlah hemoglobin (protein pengangkut 
oksigen di bawah normal,sebagian besar wanita hamil mengalami anemia yang tidakmembahayakan tetapi anemia akibat kelainan bawaan pada hemoglobinbisa mempersulit kehamilan, kelainan tersebut meningkatkan resikopenyakit dan kematian pada bayi baru lahir dan meningkatkan penyakitpada ibu[25]. Darah menyuplai nutrisi ke jaringan tubuh dan mengangkut zat sebagai hasil dari metabolism serta mengangkut oksigen. Keadaan anemia dapat berefek meningkatkan bebean kerja pompa jantung[26].

Menurut Ermawati (2017) setiap 100 gram Psidium Guajava memiliki kandungan senyawa aktif yang dapat menaikkan hb dalam darah, diantaranya: zat besi, kalsium, fosfor vitamin A dan C. Vitamin $\mathrm{C}$ adalah salah satu zat untuk membantu proses penyerapan zat besi. Jika kekurangan zat besi maka dapat menyebabkan penurunan daya kekebalan tubuh dan sering merasakan letih[10]. Utaminingtyas (2017) juga mengatakan bahwa umbi bit merupakan alternatif pengobatan non farmokologi mengandung zat besi yang dapat meningkatkan kadar hemoglobin [13]. Bit dengan kadar air yang cukup tinggi dan memiliki kandungan vitamin A, B, dan C. Selain itu, bit juga mengandung karbohidrat, protein, dan lemak yang berguna untuk kesehatan tubuh. Mineral lainnya juga terkandung dalam bit seperti zat besi, kalsium dan fosfor[20].

Sejalan dengan penelitian Putri, et al., (2017) yang mengatakan bahwa ada perbedaan kadar $\mathrm{Hb}$ ibu hamil yang mengonsumsi tablet Fe dan tablet Fe+Jus jambu biji merah[27]. Peryataan tersebut juga sesuai dengan penelitian Suryandari \& Happinasari (2015), tentang pemberian jus bit pada seluruh ibu hamil yang berada di wilayah kerja Puskesmas Purwokerto Selatan. dengan intervensi yang diberikan selama 7 hari sebanyak 500 cc dengan hasil. Rerata kadar $\mathrm{Hb}$ ibu sebelum dan sesudah konsumsi $\mathrm{Fe}$ dan jus buah bit adalah 9,7 g/dl menjadi 10,3 g/dl. Artinya terdapat perbedaan kadar $\mathrm{Hb}$ setelah pemberian Fe dan Fe dengan buah bit[12].

Hasil penelitian Liananiar, et al (2020) pada kelompok pemberian buah bit terdapat ratarata selisih kadar hemoglobin sebelum dan sesudah mendapatkan intervensi buah bit sebanyak 4.000 gram selama 5 minggu adalah $12,0 \mathrm{mg} / \mathrm{dL}$. Sedangkan selisih untuk kelompok yang tidak diberikan buah bit (kontrol) yaitu 9,5 $\mathrm{mg} / \mathrm{dL}$. Berdasarkan distribusi rata-rata kadar hemoglobin kelompok eksperimen menurut pengukuran pre test bahwa terjadi peningkatan rata-rata kadar hemoglobin ibu hamil trimester III sebesar 11,517 gr/dl. Terdapat pengaruh konsumsi buah bit terhadap kadar hemoglobin ibu hamil dengan $\rho$ value lebih kecil dari nilai alpha $(0,05)$. [21]

Menurut asumsi peneliti perubahan kadar hb tersebut bukan hanya dipengaruhi dari tablet $\mathrm{Fe}$ dan subtansi tambahan seperti jus jambu biji merah dan jus bit. Faktor lain yangh menjadi pendukung utama adalah pemenuhan nutrisi seimbang selama kehamilan yang dapat mencegah terjadinya anemia. Vitamin $\mathrm{C}$ da $\mathrm{Fe}$ di dalam jus jambu biji merah dan jus bit akan membantu proses penyerapan $\mathrm{Fe}$ dalam tubuh ibu. Selain itu, konsumsi jus jambu biji merah maupun jus buah bit setiap hari pada ibu tidak memiliki efek samping dan cocok untuk ibu hamil yang tidak suka mengonsumsi obat-obatan atau vitamin selama masa hamil. 


\section{Hasil Bivariat}

Tabel 2.

Perbedaan Sebelum dan Sesudah kadar hemoglobin ibu hamil pada kelompok jus jambu biji merah dan kelompok jus bit

\begin{tabular}{lccccccc}
\hline \multirow{2}{*}{ Kelompok } & \multicolumn{2}{c}{ Pretest } & \multicolumn{2}{c}{ Posttest } & \multirow{2}{*}{$T$} & p-value \\
\cline { 2 - 5 } & $\mathrm{M}$ & $\mathrm{SD}$ & $\mathrm{M}$ & $\mathrm{SD}$ & & \\
\hline Intervensi I & 8,420 & 0,3688 & 11,513 & 1,0267 & $-17,054$ & 0,000 \\
\hline Intervensi II & 8,560 & 0,3481 & 10,153 & 0,9606 & -9.178 & 0,000 \\
\hline
\end{tabular}

Tabel 3.

Perbedaan efektifitas pemberian jus jambu biji merah dan jus bit terhadap kadar hemoglobin ibu hamil

\begin{tabular}{cccccccc}
\hline & \multicolumn{2}{c}{ Intervensi I } & \multicolumn{2}{c}{ Intervensi II } & \multirow{2}{*}{$t$} & p-value \\
\cline { 2 - 5 } & $\mathrm{M}$ & $\mathrm{SD}$ & $\mathrm{M}$ & $\mathrm{SD}$ & & \\
\hline Post Test & 11,513 & 1,0267 & 10,153 & 0,9606 & & 3,746 & 0,001 \\
\hline
\end{tabular}

Berdasarkan Tabel 2 didapatkan bahwa, intervensi I diperoleh nilai $\mathrm{p}=0,000$, artinya terdapat perbedaan ratarata kadar $\mathrm{hb}$ pretest dan posttest. Sedangkan pada Intervensi II diperoleh $p$ value 0,000 , artinya ada perbedaan ratarata kadar hemoglobin pretest dan posttest. Sedangkan pada hasil uji t-test pada Tabel 4 terdapat perbedaan efektifitas pemberian jus jambu biji merah dan jus bit terhadap kadar hemoglobin ibu hamil ( $p$-value 0,001).

Sekitar $95 \% \mathrm{Hb}$ mengandung zat besi yang berguna untuk membawa oksigen untuk diedarkan ke seluruh tubuh agar tubuh dapat melakukan metabolisme[5].

Selain dipengaruhi oleh tablet $\mathrm{Fe}$, kadar hb ibu hamil juga didukung dengan cara konsumsi makanan yang mengandung zat yang dibutuhkan dalam sistesis hemoglobin. Kandungan vitamin $\mathrm{C}$ yang dibutuhkan dalam sintesis globin akan memudahkan proses penyerapan $\mathrm{Fe}$ dan perubahan kadar hemoglobin dalam tubuh ibu[28].
Menurut Ermawati

(2017), kandungan yang terdapat pada jambu biji merah seperti vitamin $\mathrm{C}: 228 \mathrm{mg}$ dan besi : 0,26 mg, jika dibandingkan pada ubi bit yang hanya memiliki kandungan vitamin $\mathrm{C}$ sebanyak 4,9 $\mathrm{mg}$ dan dan zat besi $0,8 \mathrm{mg}$, maka buah jambu biji merah lebih tinggi dari pada ubi bit[10]. Sejalan dengan penelitian Yanuaringsih(2018) mengatakan bahwa terdapat perbedaan efektifitas pemberian jus Psidium Guajava dengan mengkonsumsi sereal terhadap perubahan kadar hb ibu hamil ( $p$ value 0,01), ratarata kadar $\mathrm{Hb}$ setelah diberikan jus jambu biji merah $12,5 \mathrm{gr} / \mathrm{dl}$ dan konsumsi sereal $11,8 \mathrm{gr} / \mathrm{dl}[22]$.

Hal ini tidak sejalan dengan penelitian yang dilakukan oleh Yuviska (2019) dimana nilai rata-rata $\mathrm{Hb}$ ibu sebelum konsumsi jus jambu biji adalah $10,107 \mathrm{~g} / \mathrm{dl}$ dan sesudah konsumsi menjadi $10,813 \mathrm{~g} / \mathrm{dl}$. Sedangkan rata-rata $\mathrm{Hb}$ pada ibu kelompok jus jambu biji merah sebelum konsumsi jus jambu biji adalah $10,040 \mathrm{~g} / \mathrm{dl}$ sesudah konsumsi jus jambu biji merah menjadi 10,507 g/dl[29]. 
Winarni, et al (2020) dalam penelitiannya mengatakan pemberian jus jambu biji merah dapat menjadi alternative dalam meningkatkan kadar hemoglobin pada ibu hamil anemia[23]. Yantina (2018) dalam penelitiannya juga menyimpulkan ada pengaruh konsumsi jambu biji merah terhadap kadar hemoglobin pada ibu hamil trimester I[24].

Menurut asumsi peneliti dalam penelitian ini, anemia yang terjadi pada ibu hamil terjadi karena banyak faktor, selain karena kurangnya pemenuhan tablet $\mathrm{Fe}$, kurangnya asupan nutrisi, dan faktor pengahambat penyerapan zat besi ada juga faktor dari usia ibu, jarak kehamilan, usia kehamilan ibu, KEK, pendidikan dan ekonomi. Dengan pemenuhan nutrisi saat hamil baik konsumsi sayur dan buah yang kaya akan vitamin $\mathrm{C}$ dan zat besi mampu membantu ibu hamil untuk mencegah terjadinya anemia atau mengatasi anemia kehamilan yang terjadi pada ibu hamil.

\section{KESIMPULAN}

Berdasarkan hasil penelitian di puskesmas Rangkapan Jaya Depok dapat simpulkan bahwa adanya perubahan kadar hb yang diberikan pada kelompok intervensi jus jambu biji merah dengan nilai rata-rata $8,4 \mathrm{~g} / \mathrm{dl}$ menjadi $11,5 \mathrm{~g} / \mathrm{dl}$. Adanya perubahan kadar hb yang diberikan pada kelompok intervensi jus bit dengan nilai rata-rata $8,5 \mathrm{gr} / \mathrm{dl}$ menjadi $10,1 \mathrm{~g} / \mathrm{dl}$. Ada perbedaan efektifitas antara jus jambu biji merah dan jus bit. Dimana Jus Jambu biji merah lebih efektif terhadap perbedaan kadar hemoglobin ibu hamil anemia. $(p=0,001)$. Sarannya diharapkan ibu hamil selain mengkonsumsi tablet $\mathrm{Fe}$ juga dapat mengkonsumsi buah jambu biji merah ataupun bit.

\section{DAFTAR PUSTAKA}

[1] Saifuddin AB. Buku Acuan Nasional Pelayanan Kesehatan Maternal dan Neonatal. Jakarta: Yayasan Bina Pustaka Sarwono Prawirohardjo; 2014.
[2] WHO. The global prevalence of anaemia in 2011. Who 2011:1-48.

[3] Kementerian Kesehatan RI Badan Penelitian dan Pengembangan. Hasil Utama Riset Kesehatan Dasar. Kementrian Kesehat Republik Indones 2018:1-100.

[4] Pratiwi AM, Fatimah. Patologi Kehamilan: Memahami Berbagai Penyakit Dan Komplikasi Kehamilan. Yogyakarta: Pustaka Baru; 2019.

[5] Tarwoto. Buk Saku Anemia Pada Ibu Hamil. Jakarta: Trans Info Medikal; 2017.

[6] Suheni R, Indrayani T, Carolin BT. Pengaruh Pemberian Telur Ayam Ras Rebus Terhadap Peningkatan Kadar Hemoglobin Pada Ibu Hamil Di Puskesmas Walantaka Kota Serang. Jakhkj 2020;6:1-12.

[7] Suheti E, Indrayani T, Carolin BT. Perbedaan Pemberian Jus Daun Kelor (Moringa Oleifera) Dan Kacang Hijau (Vigna Radiata) Terhadap Ibu Hamil Anemia. Jakhkj 2020;6:1-10.

[8] Novelia S, Dewi A, Melinasari S, Widowati R, Carolin BT. Iron and Orange Extract on Hemoglobin among Anemic Pregnant Women in Nusa Tenggara Barat in 2018. ACHNR J 2020;2:8-12.

[9] Widowati R, Carolin BT. Comparison between the Effectiveness of Tomatoes Juice and Spinach Juice Consumption on Hemoglobin Level of Third Trimester Mothers with Anemia 2021;10:931-7.

https://doi.org/10.30994/sjik.v10i1.7 38.

[10] Ermawati D, Jogjakarta PI. Keajaiban Buah dan Sayur Warna 
Kuning-Orange dan Merah. Yogyakarta: Andi; 2017.

[11] Stephana W, Utami S, Elita V. Efektivitas Pemberian Jus Buah Bit Terhadap Kadar Hemoglobin Ibu Hamil Dengan Anemia. J Online Mhs Bid Ilmu Keperawatan 2018;5:334-41.

https://doi.org/10.21608/aafu.2016.1 4660.

[12] Suryandari AE, Happinasari O. Perbandingan Kenaikan Kadar $\mathrm{Hb}$ pada Ibu Hamil yang Diberi Fe dengan $\mathrm{Fe}$ dan Buah Bit di Wilayah Kerja Puskesmas Purwokerto Selatan. Perbandingan Kenaikan Kadar $\mathrm{Hb}$ Pada Ibu Hamil Yang Diberi Fe Dengan Fe Dan Buah Bit Di Wil Kerja Puskesmas Purwokerto Selatan 2015;VII:3647.

[13] Utaminingtyas F. Manfaat Buah Bit (Beta vulgaris) Terhadap Peningkatan Kadar Haemoglobin (Hb) Ibu Hamil. J Ilm Kesehat ArRum Salatiga 2017;2. https://doi.org/https://doi.org/10.364 09/jika.v2i1.9.

[14] Black RE, Victora CG, Walker SP, Bhutta ZA, Christian P, De Onis M, et al. Maternal and child undernutrition and overweight in low-income and middle-income countries. Lancet 2013;382:427-51. https://doi.org/10.1016/S01406736(13)60937-X.

[15] Pratiwi AM, Fatimah. Patologi Kehamilan: Memahami Berbagai Penyakit dan Komplikasi Kehamilan. Yogyakarta: Pustaka Baru Press; 2019.

[16] Padila. Buku ajar: Keperawatan Maternitas. Yogyakarta: Nuha Medika; 2014.
[17] Erdina A. Perbedaan Kadar Hemoglobin antara Peroko Pasif dengan Bukan Perokok Pada siswa SMA kelas X dan XI di Sukoharjo. Sebelas Maret, 2016.

[18] Depkes RI. Profil Kesehatan Indonesia Tahun 2015. Jakarta: 2015.

[19] Ermawati D, Permata Ilmu Yogyakarta. The Miracle Of Colors, Keajaiban Buah Dan Sayur Warna Kuning, Orange Dan Merah. Yogyakarta: Andi; 2018.

[20] Puslitbangkes. Riset Kesehatan Dasar 2013. Jakarta: 2013.

[21] Liananiar, Harahap FSD, Liesmayani EE. Analisis Pengaruh Konsumsi Buah Bit Terhadap Peningkatan Kadar Hemoglobin Pada Ibu Hamil Trimester III. Heal Care J Kesehat 2020;9:1-8. https://doi.org/10.36763/healthcare. v9i1.49.

[22] Yanuaringsih GP, Nikmah AN. Perbedaan Effektifitas Pemberian Jus Jambu Biji Merah dan Konsumsi Sereal terhadap Perubahan Kadar Hemoglobin pada Ibu hamil di Pustu Pojok Wilayah Kerja Puskesmas Sukorame Kota Kediri. J Qual Women's Heal 2018;1:11-4. https://doi.org/10.30994/jqwh.v1i2.1 1.

[23] Winarni LM, Lestari DP, Wibisono AYG. Pengaruh Pemberian Jus Jambu Biji Merah Dan Jeruk Terhadap Peningkatan Kadar Hemoglobin Pada Ibu Hamil Anemia: A Literature Review. J Menara Med 2020;2:119-27.

[24] Yantina Y. Pengaruh Konsumsi Jambu Biji Merah Terhadap Peningkatan Kadar Hemoglobin Pada Ibu Hamil Trimester I Di Bps 
Lolita Puspita Sari Punggur

Lampung Tengah Tahun 2017. JKM

(Jurnal Kebidanan Malahayati) 2018;4:129-34.

https://doi.org/https://doi.org/10.330 24/jkm.v4i3.665.

[25] Yohana. Kehamilan dan Persalinan. Jakarta: Garda Media; 2011.

[26] Mantika AI. Hubungan Asupan Energi, Protein, Zat Besidan Aktivitas Fisik Dengan Kadar Hemoglobin Tenaga Kerja Wanita Di Pabrik Pengolahan Rambut PT. Won Jin Indonesia. Semarang: 2014.

[27] Putri AN, Isnaeni Y, Rokhanawati D. Pengaruh Jus Jambu Biji Terhadap Perubahan Kadar Hemoglobin Ibu Hamil Trimester III Yang Mengkonsumsi Tablet Fe Di Puskesmas Pakualaman Yogyakarta 2017.

[28] Maylina LA. Hubungan Antara Konsumsi Pangan Sumber Protein, Zat Besi, Dan Vitamin C Dengan Kejadian Anemia Siswa Sekolah Dasar. Jawa Timur: 2016.

[29] Yuviska IA, Armiyanti L. Perbedaan Pemberian Jus Kacang Hijau Dan Jus Jambu Biji Merah Terhadap Peningkatan Kadar Haeomoglobin. J Kebidanan 2019;5:52-60. 